\title{
PFEIFFERINELLA SP. (PFEIFFERINELLIDAE, APICOMPLEXA) INFECTING THE FRESH WATER SNAIL PIRENELLA CONICA LIGHT AND ELECTRON MICROSCOPE STUDIES
}

\section{By}

\author{
HODA M. EL-FAYOMI, HAYAM MOHAMMED AND THABET SAKRAN \\ Department of Zoology, Faculty of Science, Beni Suef University, Beni Suef, Egypt \\ Abstract
}

Coccidian oocysts were proved to be found in 70 of 100 collected Pirenella conica snails, with a natural infection of $70 \%$. It was observed that, Pfeifferinella sp. was transferred between hepatopancreas and small intestine of snail. The prepatent period of Pfeifferinella $s p$. infecting P. conica snails ranged from 14-18 days and the patent period was reached 50 days (P.I.). Merogony stages were the early stages observed in this study. These stages were observed in the hepatopancreas and in a large clear parasiteophorous vacuole (PV). In snails killed 4 days P.I. immature meronts were measured $12 \times 10 \mu \mathrm{m}$ containing 8 nuclei. Meanwhile, mature meronts with about 6 differentiated merozoites were detected as early as 6 days P.I., and measured $3.1 \times 1.4 \mu \mathrm{m}$. The earliest gametogonic stages were seen in the intestine of Pirenella conica snails killed 12 days P.I. Microgamonts contained about 4 nuclei and measured 7.9x6.7 $\mu \mathrm{m}$. The macrogamonts measured $7.3 \times 5.6 \mu \mathrm{m}$. Macrogametes were characterized by the presence of the vaginal tube, this tube measured $4.3 \times 1.1 \mu \mathrm{m}$. Fertilization was occurred in the intestine of the infected snails at 12 days P.I. Zygotes developed into young oocysts after fertilization.

Sporogony occurred in the intestine. In the earliest stage, the nucleus of young oocyst was occupied the central position that were observed through the examination of the intestine of infected Pirenella snails at 14 day P.I. These oocysts were found to be colorless and ellipsoid or spherical in shape measured $9.5 \times 8.5 \mu \mathrm{m}$. The oocyst wall consists of two layers, micropyle and micropyle cap were not observed in these oocysts, and wall forming bodies were arranged at the periphery of oocyst directly under the developed oocyst wall. Sporulated oocyst contains 8 sporozoites filling the entire cavity of the oocyst without sporocyst formation. Fully sporulated oocysts were excreted in the faces of infected snails from 14-18 day P.I., these oocysts measured $9.5 \mathrm{x} 8.5 \mu \mathrm{m}$. Micropyle was absent and while a residual body was observed.

Key words: Egypt, Beni Suef Governorate, Pfeifferinella sp, Pirenella conica, Morphology.

\section{Introduction}

Coccidia are protozoan parasites belonging to sporozoa. According to certain ultrastructural characters, these are given the name Apicomplexa (Levine, 1988). Apicomplexans have a complex life cycle that involves 3 replicative phases termed merogony, gamogony and sporogony (Levine, 1985a).

About one third of the approximately 4,600 described species in were placed in family Eimeriidae, and the vast majority of these species were characterized from a single life-cycle stage, the copulated oocyst (Bandoni and Duszynski, 1988). Moreover, the oocysts of Tyzzeria. alveocystis contain eight naked sporozoites, absence of sporocysts (Levine, 1985b), family Pfeifferinellidae genus Pfeifferinella, characterized by oocysts with 8 naked sporozoites without forming sporocysts and macrogamete has vaginal tube, which considered as a family distinct characters (Levine, 1973, 1985b). Investigations of coccidian parasites infecting invertebrates lag generally behind those of vertebrate hosts. Records on coccidia infecting invertebrate hosts are scattered and fragmented. From Pulmonate gastropods yet many coccidian parasites have infrequently been reported, this includes parasites of the families Adeliedae (Klossia), Eimeriidae (Isospora, barrouxia and Alveocystis) and Pfeifferinellidae (Pfeifferinella), Fritsche (1987).

The genus Pfeifferinella was created by Wasielewski (1904) for the coccidian parasite described from the gut contents and hepatopancreas of the water snail Planorbarius corneus in Germany. This parasite 
was given the name Pfeifferinella ellipsoides. Leger and Hollande (1912) described a second species $P$. impudica from the hepatopancreas of the slug Limax margina$t u s$, in France. Then, family Pfeifferinellidae was established by Grasse (1953). Wacha (1980) USA described a third species $P$. gugleri from the hepatopancreas of land snail, Triodopsis albolabris. The fourth spcies $P$. egypti was described from Lanistes carinatus in Egypt (Abdel-Ghaffar et al, 1995). This family is a monoxenous group of parasites in which fertilization of macrogametes occur via the vaginal tube were the diagnostic character of the family (Levine, 1985b). However, in the genus Alveocystis fertilization occurs without a vaginal tube. So, Levine (1985a) stated that a vaginal tube was not a characteristic feature and described a first species of Alveocystis in the land snail Triodopsis cobolabris, a seco nd species $A$. cleopatra was described from hepatopancreas cells of fresh water snail Cleopatra bulimoides (Sakran, 1997).

The present work aimed at the study of incidence and prevalence of coccidian parasites among the most abundant pulmonate gastropods snails, Pirenella conica, Viviparus sp. which is fresh water snail collected randomly from Shreef-Basha and ReyadBasha canal at Beni-Suef (Upper Egypt), also the parasite life cycle was studied in experimental infected snails by light microscopy and electron microscopy

\section{Material and Methods}

In the present study, 100 Pirenella conica of different ages were collected from BeniSuef water sources. All snails were identified after Danish Bilharziasis Laboratory (1983). Oocysts were collected and concentrated by floatation technique (Long et al, 1976), washed several times with distilled water to remove the effect salinity. The recovered oocysts were suspended in 2.5\% potassium dichromate solution and stored $4^{\circ} \mathrm{C}$ till needed. The average size of 100 sporulated oocysts was measured with an ocular micrometer calibrated against stage micrometer. Care was taken to ensure that sporulated oocysts were spread under the cover glass to prevent their overlapping.

Light microscopy: Fresh smears and frozen sections of different organs were fixed in acetone free methanol, stained with 3\% Giemsa solution in phosphate buffer $(\mathrm{PH}$ 7.3) and then examined for infection. Samples of highly infected organs were immediatly fixed in $2 \%$ Glutaraldehyde in $0.1 \mathrm{M}$ Cacodylate buffer ( $\mathrm{PH} \mathrm{7.3),} \mathrm{five} \mathrm{microns}$ sections were prepared by using a rotary microtome, stained with haematoxyline and eosin, covered and examined by light microscope.

Electron microscopy: Samples of highly infected organs were immediatly fixed in $2 \%$ Glutaraldehyde in $0.1 \mathrm{M}$ Cacodylate buffer (PH 7.3) at $4^{\circ} \mathrm{C}$ for at least $4 \mathrm{hrs}$. After washing in cacodylate buffer, postfixation was done in $1 \%$ Osmic acid. The specimens were dehydrated in ascending ethanol and poststained with uranyl acetate, phosphotungestic acid (70\%) and then transferred to propylene oxide and finally embedded in Araldite (Serva). Semi- and ultra thin sections were cut using a Reichert Ultramicrotom. Semithin sections were stained in methylene blue and azure. The ultrathin sections were contrasted with the uranyl acetate and lead citrate stained ones. Microscopical examination was carried out using Philipps (400 T) TEM

Experimental infection: Sixty fresh noninfected $P$. conica were isolated, their fecal materials were examined daily to prove to be coccidia free for 15 days prior to experimental infection. The coccidia-free snails were kept in aquaria with highly concentrated medium of sporulated oocysts previously identified and collected from naturally infected snails. The prepatent period and the duration of oocyst production (patent period) were recorded. The different developmental stages were killed and prepared for histological studies at 2 days interval from the second day to 32 post-inoculation. 


\section{Results}

Coccidian oocysts were proved to be found in 70 of 100 collected $P$. conica. In naturally infected snails, it was observed that Pfeifferinella $s p$. was transferred between hepatopancreas and small intestine of the snail. The parasite changed its site according to the development stages, but none was detected in other parts of snail.

a- Prepatent and patent periods: In a group of 20 experimentally infected $P$. conica individuals passed oocysts as early as 14 days P.I., whereas seven snails did not pass any oocysts until 16 days post-infection, the others shedded oocysts $18^{\text {th }}$ day P.I. This indicated that the Pfeifferinella sp. prepatent period in $P$. conica ranged from 1418 days. The patent period or duration of oocyst production was determined in twenty snails. Eight of experimentally infected snails discharged oocysts for 20 days only, seven snails passed oocysts for 42 days, and five snails discharged oocysts up to 50 days P.I. Therefore, it was clear that the patent period was up to 50 days P.I.

b- Histological study of the endogenous stages: 1-Merogony: Regarding the endogenous stages observed during the histological study of the parasite, merogonic stages were the early stages observed in this study. These stages were concentrated in the hepatopancreas and were found in a large clear parasiteophorous vacuole (PV). Immature spherical meronts with 4 nuclei were seen as early as 4 days P.I, measured $11.3-15 \times 8.2-13.8 \mu \mathrm{m}$ with an average of $12 \times 10 \mu \mathrm{m}$ containing eight nuclei. The nuclei were distributed randomly through the cytoplasm of the meront (Figs. 2, 2, 3). The mature meronts with about six differentiated merozoites were detected as early as 6 days P.I. Merozoites have a pointed anterior end and a rounded posterior one with a nucleus near the center. These merozoites measured 2.7-4.5x1.1-2.2 $\mu \mathrm{m}$ with an aver-

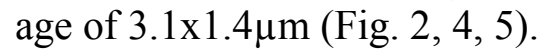

2- Gamogony: Gamonts were proved to be developed directly from merozoites. The earliest gametogonic stages were in the intestine of $P$. conica killed 12 day P.I. Microgamonts containing about four nuclei were detected at $12^{\text {th }}$ day P.I, measure 6.5$10.9 \times 4.9-8.9 \mu \mathrm{m}$ with an average of $7.9 \times 6.7$ $\mu \mathrm{m}$ (Figs. 2-6). Oval-shaped macrogametes with a single nucleus were found in intestinal of $P$. conica killed at $12^{\text {th }}$ day P.I, surrounded by clear parasitophorous vacuole. The macrogametes measure 5-10x4-9 $\mu \mathrm{m}$ $(n=15)$ with an average of $7.3 \times 5.6 \mu \mathrm{m}$ characterized by the vaginal tube (Fig.2-7).

Fertilization occurred in intestine of infected snails at $12^{\text {th }}$ day P.I. At the beginning of fertilization, anisogametes (macrogamete and microgamete) were found in a form called syzygy (Figs. 2-11). Zygotes developed into young oocysts after fertilization (Figs. 2-13).

3- Sporogony: Sporogony occurred in the tissues of the host cell as indicated by the presence of fully sporulated oocysts in stained sections of intestine. Each oocyst contains 8 sporozoites filling the entire cavity of the oocyst without sporocyst formation. Fully sporulated oocysts were excreted in the feces of infected snails 14-18 days P.I. with length ranged from $7.5 \mu \mathrm{m}$ to $13.5 \mu \mathrm{m}$ and width from $6.5 \mu \mathrm{m}$ to $12.5 \mu \mathrm{m}$, with an average of $9.5 \times 8.5 \mu \mathrm{m}$ (Fig. 2).

By TEM showed banana shaped sprozoites converted to spherical shaped young uninucleated meronts. The meronts contain central located large spherical nucleus (Fig. 1). Merogony started the nucleus division into many nuclei arranged at the periphery of multinucleated meronts (Fig. 2). With maturation a rosette shaped meront with developed merozoites were formed and each developed merozoites was banana shaped in longitudinal section, while in cross section appear as circulars arranged at periphery of the meront wall (Fig. 2). Microgamonts contain many nuclei arranged at the periphery were observed (Fig.2). On the other hand, macrogametogenesis started 
by formation of vaginal tube, which was curved in shape with tapered end. The wall of vaginal tube was thin and highly osmiophilic developed at the macrogametes' antirostral pole. The tube measures $2-6.4 \times 0.8-$ $1.5 \mu \mathrm{m}$ with an average of $4.3 \times 1.1 \mu \mathrm{m}$ (Figs. $15,16)$. The oocyst wall consists of two layers, the outer layer was light and thick $(\approx 0.6 \mu \mathrm{m})$ the inner one was dark and thin. Micropyle was absent, while a residual body was present (Fig. 2).

Life cycle of Pfeifferinella have three phases: Merogony, gamogony and sprogony within the $P$. conica. Merogony phase occurs in the digestive gland. Gamogony divides into macrogamogony and microgamogony in snail's intestine and sporogony phase occurs in snails' intestine (Fig.2).

\section{Discussion}

The family Pfeifferinellidae (suborder Eimeriina) was established by Grasse (1953). Levine (1973) provided the most recent diagnostic characters for the members belonging to this family, the oocyst without sporocysts but containing 8 naked sporozoites, fertilization of the macrogamete via the vaginal tube. Levine (1985b) stated that if the parasitic oocysts containing eight naked sporozoites and no sporocysts, it belongs one of the genera Pfeifferinella, Schellackia and Tyzzerita, as all share the genetic character, whereas vaginal tube is the most important distinctive character in Pfeifferinella. This was approved in three species of Pfeifferinella; P. ellipsoides (Wasielewski, 1904), P. impudica (Leger and Hollande, 1912) P. egypti (AbdelGhafar et al, 1995) and Pfeifferinella sp. of the present study. The four species of the genus Pfeifferinella had oocysts with single nucleus, this nucleus divides three times and gives eight nuclei, each nucleus incorporated a part of the cytoplasm and differentiated into eight naked sporozoites without forming sporocysts and macrogamete fertilization takes place through vaginal tube. On the other hand, Wacha (1980) recorded $P$. gugleri having all the characters including oocysts with 8 sporozoites, absence of sporocysts, but he did not recognize vaginal tubes in the macro gamete. Levine (1985b) reclassified this species to the genus Alveocystis and gave it a name Alveocystis gugleri.

Natural infection: The available information about coccidian parasites infecting pulmonate snails were found to be scarce, incomplete and scattered. Throughout the genus Pfeifferinella, $P$. ellipsoides was found naturally infecting Panorbarius corneus snail in Germany (Wasielewski, 1904), land snail Limax marginatus in France $P$. impudica was reported (Leger and Hollande, 1912). A third species of Pfeifferinella infects Triodopsis albolabris snail in USA and $P$. gugleri was added by Wacha (1980). Also, Stagnicola elodes Physa gyrina and Aplexa hypnorum pulmonate were reported by Fritsche (1987) to be hosts for $P$. ellipsoides. Levine (1973; 1985b) gave criteria of genus Pfeifferinella that includes oocysts containing eight naked sporozoites, without sporocysts and fertilization of the macrogamete occurred through a vaginal tube, and that absence of one of these characters would eliminate the need for a separate family.

In the present study, rate of natural infection with coccidian oocysts was found to be $70 \%$. This infection rate was very high as compared with those reported in other pulmonate snails. Fritsche (1987) recorded that the infection rate of coccidian oocysts in various species of pulmonate snails was $16 \%$ from different Rivers and Ponds in Washington and Minnesota. The coccidian oocysts were $P$. ellipsoides, Alveocystis gugleri and unidentified coccidian oocysts. He added that the infection rate with $P$. ellipsoides was 21\% from Stagnicola elodes snails in Stright River and Mahnomen Pond, 2\% from Physa gyrina in Ceder River and $6 \%$ for Aplexa hypnorum in Mahnomen Pond. This indicated that the highest rate of natural infection among pulmonate snails recorded in the present study may be 
attributed to the habitat of the snails both ecologically and geographically The oocyst is most easily accessible stage of coccidia, and many species are known only by the characters of their oocysts (Joyner \& Long, 1974 and Abdel-Ghaffar et al 1991). The non-sporulated oocysts of the Pfeifferinella $\mathrm{sp}$. in the tissues of naturally infecting $L a$ nistes snails were ellipsoid or spherical in shape. The oocyst wall consists of two layers. The outer layer was light and thick $(0.6$ $\mu \mathrm{m})$, the inner one was dark and thin which was difficult to measure, fresh sporulated oocysts were ellipsoid, spherical or subspherical in shape. The oocyst $(0.6 \mu \mathrm{m})$ and the inner layer was dark and thin surrounding the eight naked sporozoites. This finding agrees with, that of Wacha (1980) who reported two layered oocyst wall in $P$. gugleri. This wall was about $0.6 \mu \mathrm{m}$ and contained 8 naked sporozoites. Wasielewski (1904) found that P. ellipsoides oocysts measure $15 \times 13 \mu \mathrm{m}$. A micropyle was lacked but a residual body was present and the sporozoites measured $12 \times 1.5-2 \mu \mathrm{m}$. Fritsche (1987) measurements were 19.2-16.8x13.6 $\mu \mathrm{m}$ for oocysts, sporozoites measured 12.3$9.2 \times 2.3-1.5 \mu \mathrm{m}$ in Stagnicola elodes host, whereas in Physa gyrina oocysts measure 20.0-18.4x $12.8-11.2 \mu \mathrm{m}$ and the sporozoites measure $18.0-12.0 \times 3.0-2.4 \mu \mathrm{m}$. On the other hand, Leger and Hollande (1912) reported $20 \times 10 \mu \mathrm{m}$ for the ovoid shaped oocysts of $P$. impudica with oocysts containing micropyle and a residual body. Wacha (1980) reported ovoid oocysts measured 32-18.5x $16.5-13 \mu \mathrm{m}$ of $P$. gugleri these oocysts contain micropyle and residual body and sporozoites measured $13 \times 2.5 \mu \mathrm{m}$. In the present study, unsporulated oocysts from naturally infected snails were 13.5-7.5x11.5-6.5 $\mu \mathrm{m}$, while, fresh sporulated oocysts measure 13.5-7.5x12.5-6.5 $\mu \mathrm{m}$. Micropyle was absent, but the residual body was present. The sporozoites measure $6.7-4.4 \times 2-1 \mu \mathrm{m}$.

Regarding the size of sporulated oocyst reported for the genus Pfeifferinella the above mentioned reports show a high range of variation in both length and width of oocysts. The oocyst reported in the present study (Pfeifferinella sp.) seems to be the smallest one and the oocyst of P. gugleri in Triodopsis albolabris reported by Wacha (1980) to be the largest one.

One of the most important features of coccidian parasites is the specify site of infection. Wasielewski (1904) stated that all developmental stages of $P$. ellipsoides (merogony, gamogony and sporogony) occurred in hepatopancreas cells of Planorbarius corneus snails. This opinion agreed with that of $P$. impudica reported by Leger and Hollande (1912) from terrestrial slug, Limax marginatus and with $P$. gugleri reported by Wacha (1980) from land snail, Triodopsis albolabris. This suggestion partially agreed with Pfeifferinella sp. infection in the present study, whereas developmental stages of merogony were observed in the snail hepatopancreas. On the other hand gamogony and sporogony were observed in the intestine of the infected snails.

In the present study, the prepatent period of experimentally infected snails ranged from 24-28 day. Heydorn et al. (1975) reported a prepatent period from 8-9 days for Sarcocystis species, but Fayer and Kradel (1977) recorded a prepatent period from 933 day P.I. In the present study, the patent period ranged from 30-60 days. Fritsche (1987) stated that oocysts of P. ellipsoides from naturally infected snails completely disappeared from snails' feces in seven days P.I.

In the present study, the merogony process occurred via multiple fission characterized asexual reproduction in Coccidia (Levine, 1971a). Meronts of Adeleida and Sarcosporidia are characterized by their large ability to invade and develop in a wide variety of organs inside the snail host. Developmental stages proceeded gamonts formation in all cases (Moltmann, 1980; 1981).

Regarding Pfeifferinella sp. meronts' site, Wasielewski (1904) reported meronts 
of $P$. ellipsoides in $P$. corneus in hepatopancreas cells. This agreed with Leger and Hollande (1912) for meronts P. impudica infected the land snails Limax marginatus and with P. gugleri in Triodopsis albolabris. These results partially agreed with the present study. Meronts of Pfeifferinella $\mathrm{sp}$. were found in the hepatopancreas cells and digestive gland in Lanistes sp.

Merogony of coccidian parasites may occur in one generation or more. In Sarcocystis tenella only one generation of meronts was observed (Clarence et al, 1982). On the other hand, merogony may occur in three generations as in S. sybillenis (Dubey et al, 1983). Meanwhile four generations of merozoites were described in Klossia lossi (Nabih, 1938), but successive merogonic generations were not clearly distinguished in kidney tissue (Moltmann, 1981). In previous studies of genus Pfeifferinella, number of merogonic generations was not recorded, whereas in the present study two merogonic generations were found in the cells of hepatopancreas of Lanistes sp.

In the present study, uninucleated meronts of first merogonic generation measure $3.3 \times 2.5 \mu \mathrm{m}$, while immature meronts measure $12 \times 10 \mu \mathrm{m}$. About 20-25 merozoites were found in mature meronts measuring $3.1 \times 1.4 \mu \mathrm{m}$. The uninucleated meronts of the second generation measure $6.5 \times 5.5 \mu \mathrm{m}$. Mature meronts measure $26.7 \times 17.7 \mu \mathrm{m}$ and gave about 60 merozoites, each merozoite measure $4.5 \times 2 \mu \mathrm{m}$. In the present study, the size of meronts and number of merozoites in the second generation meronts were larger than those of the first generation. Wasielewski (1904) reported meronts of $P$. ellipsoides infecting Planorbarius corneus measured 20 times in diameter and each meront gave 60 merozoites. This number of merozoites was the same as reported by Leger and Hollande (1912) for P. impudica, whereas meronts were larger in size and measured $30 \mu \mathrm{m}$ in diameter. Meront of $P$. gugleri measures $20 \times 15 \mu \mathrm{m}$ and gave about 24-25 merozoites that measure $8-10 \times 2 \mu \mathrm{m}$ with a nucleus located in posterior third (Wacha, 1980).

In the present study, gamonts (macrogamonts and microgamonts) occupied the epithelial cells of intestine and cells of digestive gland in Lanistes sp. But, Wasielewski (1904) found gamogony of $P$. ellipsoides in hepatopancreas cells. This agreed with Leger and Hollande (1912) for P. impudica and Wacha (1980) for P. gugleri.

$P$. ellipsoides was described from $P$. corneus collected from East Germany (Wasielewski, 1904). Leger and Hollande (1912) claimed that sexual development of $P$. ellipsoides occurred in a site similar to that described for $P$. impudica in the hepatopancreas, including the formation of a vaginal tube in the macrogamete which was considered, according to Levine (1971 a), family Pfeifferinellidae the main character. In the present study, macrogametes of Pfeifferinella sp. measure $7.3 \times 6.5 \mu \mathrm{m}$, with a single prominent nucleus. The antirostral poles give a narrow eosinophilic tube measure 3.3 p.m. This agreed with Leger and Hollande (1912) who stated that macrogametes of $P$. impudica were ovoid, measure $15-10 \mu \mathrm{m}$. The nucleus of macrogamete contains karyosomes and cytoplasm with numerous reserve granules and a few chromatic masses. A rostral and an antirostral poles was distinguishable in the macrogametes. They added that the antirostral pole gives rise to temporary, narrow, eosinophilic, tube-like structure, the vaginal tube which protruded into the host intestinal lumen. Thus providing a tube at which the microgametes enter and fertilize macrogamete. This disagreed with Wacha (1980) for macrogamete of $P$. gugleri that lack a vaginal tube, the nucleus of macrogamete contains karyosomes and the cytoplasm had numerous granules and a few wall-forming bodies. He preferred that the wall-forming bodies could be the chromatic masses in $P$. impudica (Leger and Holland, 1912). The size of Pfeifferinella macrogametes in the present study seemed to be smaller than 
that reported by Leger and Holland (1912) the same species and that of $P$. gugleri reported by Wacha (1980).

Microgamonts of $P$. impudica (Leger and Hollande, 1912) measured 40-50 $\mu \mathrm{m}$ giving rise to numerous microgametes of $0.4 \mu \mathrm{m}$ or smaller. Wacha (1980) reported that microgamonts of $P$. gugleri were ellipsoide to ovoide or spherical, measured 15.0 $\mathrm{x} 11.5 \mu \mathrm{m}$ and occasionally with a residual body. These gamonts produced minute microgametes too numerous to be counted. In the present study, immature microgamonts measure $7.9 \times 6.7 \mu \mathrm{m}$; mature microgamonts measure $18.6 \times 11.9 \mu \mathrm{m}$, and flagellated microgametes with central nucleus measure $5.0 \times 3 \mu \mathrm{m}$ with $30 \mu \mathrm{m}$ long flagellum. These microgametes were largest in size in contrast to those of $P$. impudica reported by Leger and Hollande (1912) and microgamete of $P$. gugleri reported by Wacha (1980).

Sporogony started after fertilization of the macrogametes forming young oocyst, (Mehlhorn and Hydron, 1978). The process of sporogony occurred internally like Sarcocystis (Mehlhorn and Scholtyseck, 1974), or externally as that of Eimeria and Isospora (Duszyniski and Snell, 1990).

In the present study, sporogony occurred in the intestine of the infected snails that started by division of the oocyst nucleus into 2 nuclei, each one subdivided two times and the oocyst contains 8 nuclei, each nucleus incorporated part of the cytoplasm forming 8 sporozoites without sporocyst formation. This result agreed with sporogony of $P$. ellipsoides (Wasielewski 1904) and $P$. impudica (Leger and Hollande, 1912), whereas partially disagreed with Wacha (1980) who stated that sporogony of $P$. gugleri occurred internally in the tissues and externally in feces. However, Moltmann (1981) recorded that in the sporogony of $K$. helicina the cytoplasm of the oocyst was divided into about 150 sporoblasts simultaneously. Each one of them contained two nuclei. Subsequently four sporo- zoites were developed inside each sporocyst.

\section{References}

Abdel-Gaffar, F, Bashtar, AR, Mostafa, AM, El-Toukhy, A, 1991: Eimeria arvicanthi Van den Berghe \& Chardome 1956 and Eimeria mehlhorni nov. sp. Infecting the field rat Arvicanthis niloticus in Egypt. Arch. Protistenkd. 140:185-90.

Abdel-Gaffar, F, Sakran, Th, Fayed, H, Mohmed, H, 1995: Life cycle of Pfeifferinella egypti (n.sp.) infesting fresh-water snail from lanistes carinatus snail in Egypt. J. Egypt. Ger. Soc. 16, D:25-48.

Allen, EA, 1936: Tyzzeria perniciosa gen. \& sp. nov., a coccidium from the small intestine of the Pekin duck, Anas domesticus. Arch. Protistenked. 87:262-7.

Andrews, JM, 1926: Coccidiosis in mammals. Amer. J. Hyg. 6:784-98.

Bandoni, SM, Duszynski, DW, 1988: A plea for improved presentation of type material for coccidia. J. Parasitol. 74, 4:519-23.

Clarence, A, Speer, CA, Dubey, JP, 1982: Scanning and transmission electron microscopy of ovine-mesentric arteries infected with first generation meronts of Sarcocystis tenella. Canad. J. Zool. 60, 2:203-9.

Comelissen, AWC, Overdulve, JP, Vander, PM, 1984: Determination of nuclear DNA of five Eucoccidian parasites, Isospora, Toxoplasma gondii. Sarcocystis cruzi, Eimeria tenella, E. acervulina and Plasmodium berghei withspecial reference to gamontogenesis and meiosis in T. gondii. Parasitol. 88:531-53.

Danilewsky, VY, 1885: Zur Parasitologie des Blutes. Biol. Zbl. 5:37-529.

Danish Bilharziasis Laboratory 1983: A field guide to fresh water snails in countries of the WHO Eastern Mediterranean region. (WHO Collaborating center for Applied Malacology) Jaegersborg Alle ld DK 2920 Charlottenlund Denmark.

Dubey, JP, Jolley, WP, Torn, TE, 1983: Sarcocystis sybillensis $\mathrm{sp}$. nov. from the north American elk (Cervus elephus). Canad. J. Zool. 61, 4:732-42.

Duszynski, DW, Snell, HL, 1990: Three new coccidia (Apicomplexa) from the hood island lizard, Tropidurus delanonis frorn the Galapagos archipelago. J. Parasitol. 76, 3: 313-8. 
Fayer, R, Kradel, D, 1977: Sarcocystis leporum in cottontail rabbits and its transmission to Carnivores. J.WIDI. 13:170-3.

Fleischmann, B, 1977: Elektronenmikroskopischer Beitrag zum parasit Wirt-Verhaltnis des Coccids Klossia helicina (Coccidia, Adeleidea). Dissertation, Math.-Nat.Fak., Universitat Bonn.

Fritsche, TR, 1987: Studies on the coccidian parasites (Apicomplexa Eimeriidae and Pfeifferinellidae) of pulmonate gastropods. J. Protozool. 34, 1:75-8.

Grasse, PP, 1953: Classe des coccidiomorphes (Coccidiomorpha Doflein, 1901-Coccidies des auteurs) in Grasse, PP, ed., Traite de Zoologie, Masson, Paris.

Heydorn, AO, Gestrich, R, Mehlhorn, H, Rommel, H, 1975: Proposal for a new nomenuclature of Sarcosporidia. Z. Parasitenkd. 48: 73-82.

Jakowska, S, Nigrelli, RF, 1956: Babesioso$m a$ gen. nov. and other babesioides in erythrocytes of cold-blooded vertebrates. Ann. N.Y. Acad. Sci. 64:112-7.

Joyner, LP, Longs PL, 1974: The specific characters of Eimeria with special reference to the coccidia of the fowl. Avian Pathol. 3, 3:145-57.

Kheisin, EM, 1956: Sistema sporovikov. taxonomy of the sporozoa in Russian. Zool. Zh. 35:1281-98.

Kloss, H, 1855: Uber parasiten in der niere von Helix. Abh. Senckenberg. naturforsch. Ges. 1: 189-213.

Leger, N, Duboscq, O, 1910: Selenococcidium intermedium leg. et Dub. Ia systematique des sporozoaires. Arch. Zool. Exp. Gen. Ser. 5, 5: 187-238.

Leger, L, 1911: Caryospora simplex, coccidie monosporee et laclassificatiofl de coccidies. Arch. Protistenkd. 22:71-88.

Leger, L, Hollande, AC, 1912: La reproduction sexuee chez les coccidies Monosporees du genre Pfeifferinella. Arch. Zool. Exp. Gen. Ser. 5, 9:1-8.

Leuckart, K, 1879: Allgemeine Naturgeschicte der Parasiten. GF, Winter Leipzig and Heidelberg.

Levine, ND, 1971a: Uniform terminology for the protozoan subphylum Apicomplexa. J. Protozool. 18:352-5.

Levine, ND, 1971b: Taxonomy of the piroplasms. Trans. Am. Microsc. Soc. 90:2-33.

Levine, ND, 1973: Introduction history and taxonomy (Coccidia). In: The Coccidia Ham- mond, DM, Long, PL, eds., Univ. Park Press, Baltimore.

Levine, ND, 1979: Agamococcidiorida ord.n. and Rhytidocystidae fam. n. for the coccidian genus Rhytidocystis Henneguy, 1907. J. Protozool. 26:167-8.

Levine, ND, 1985a: Phylum II. Apicomplexa Levine, 1970: In: Illustrated Guide to Protozoa. By JJ, Lee, SH, Hutner, EG, Bovee. Society of Protozoologists, Lawrence, Kansas.

Levine, ND, 1985b: Species of the coccidian genus Alveocystis. J. Protozool. 32, 2:368-9.

Levine, ND, 1988: The protozoan phylum Apicomplexa CRC. Press, Inc. Boca Raton, Florida.

Levine, ND, Corliss, JO, Cox, FEG, Deroux, G, Grain, J, et al, 1980: A newly revised classification of the protozoa. Protozool. 27, 1:3758.

Long, PL, Jouner, LP, Millard, BJ, Norton, C, 1976: A guide to laboratory techniques used in the study and diagnosis of avian coccidiosis. Folia Vet. Lat. 6:201-17.

Mehlhorn, H, 1988: Parasitology in Focus. Springer-Verlag Berlin, Heidelberg, New York, London, Paris, Tokyo.

Mehlhorn, H, Scholtyseck, E, 1974: Light and electron microscope studies on stages of Sarcocystis tenella in the intestine of cats. Z. Parasitenkd. 58:251-70

Mehlhorn, H, Hydron, AO, 1978: The Sarcosporidia (Protozoa: Sporozoa): Life cycle and fine structure. Adv. Parasitol. 16:43-93.

Minchin, EA, 1903: Protozoa. Sporozoa In: Lankester, ER, Treatise on Zoology, London.

Moore, EN, 1954: Species of coccidia affecting turkeys. $91^{\text {st }}$ Ann. Meet. Am. Vet. Med. Ass. Moltmann, UG, 1954: Light and electron microscopic studies on the merogony of Klossia helicina (Coccidia; Adeleidea) in snail kidney tissues cultures. Z. Parasitenkd. 62:165-78.

Moltmann, UG, 1981: Light and electron microscopic studies on Klossia helicina (Coccidia): Development of gamonts in snail kidney tissue cultures and sporogony in the natural host. Protistologica 17, 2:185-97.

Nabih, A, 1938: Studien uber die Gattung Klossia \& Beschreibung des Lebenszyklus von Klossia lossi (n.sp.). Arch. Protistenkd. 91: 471-515.

Reichenow, E, 1919: Der Entwickelungsgang der Hamococciden karyolysus und Schellakia 
n. gen. Berl. Sitzbericht Ges. Naturf. Freunde, 440-7.

Sakran, Th, 1997: Life-cycle of Alveocystis cleopatri n. sp. (Apicomplexa-Coccidia-Pfeifferinellidae) infecting fresh water snail Cleopatra bulimoides. Egypt. J. Zool. 29:111-25.

Schulte, E, 1971: Cytochemische Untersuchungen an den feinstrukturen Von Klossia helicina (Coccidia, Adeleidea). I. Morphologie und Kulturhaltung Von Klossia helicina.Z. Parasitenkd. 36:140-57.

Sinden, RE, 1985: Gametocytogenesis in Plasmodium $\mathrm{sp}$. and observations on the meiotic division. Ann. Soc, Belge de Med. Trop, 65:2133.

Sinden, RE, Hartly, RH, 1985: Identification of the meiotic division of malarial parasites. J. Protozool. 32:742-4.

Volkmann, B, 1967: Vergleichend elektronen mikros Kopische \& Lichtmikropische Untersuch-ungen an verschiedenen Entwicklungsstadien von Klossia helicina (Coccida, Adeleidea). Z. Parasitenkd. 29:159-208.

Wasielewski, T, 1904: Studies und Mikrophotogramme zur Kenntnis der Pathogenen Protozoen. JA. Barth, Leipzig.

Fig.1: Photograph of Pirenella conica shell X3

\section{Figures explanation}

Wacha, RS, 1980: On the taxonomic status of family Pfeifferinellida (Coccidia), with a description of Pfeifferinellidae guglerisp. n. sp. J. Protozool. 27:368-71.

Wenyon, CM, 1926: Protozoology: A Manual for Medical Men, Veterinarians and Zoologists. William Wood, New York.

$\begin{array}{ll}\text { DME } & \text { Developing meront } \\ \text { DMG } & \text { Developing microgamete } \\ \text { DME } & \text { Developing merozoites } \\ \text { DSP } & \text { Developing sporozoites } \\ \text { F } & \text { Flagellum } \\ \text { HC } & \text { Host cell } \\ \text { HN } & \text { Host nucleus } \\ \text { M } & \text { Meront } \\ \text { MAG } & \text { Macrogamont } \backslash \text { macrogamete } \\ \text { MG } & \text { Microgamete } \\ \text { MIG } & \text { Microgamont } \\ \text { MM } & \text { Meront memrane } \\ \text { ME } & \text { Merozoites } \\ \text { N } & \text { Nucleus } \\ \text { NG } & \text { Nucleus of the microgamete } \\ \text { OC } & \text { Oocyst } \\ \text { PV } & \text { Parasitophorous vacuole } \\ \text { RB } & \text { Residual body } \\ \text { SPR } & \text { Sporozoite } \\ \text { WFB } & \text { Wall forming bodies } \\ \text { Zy } & \text { Zygote }\end{array}$

Figs.2-5: Merogonic stages of Pfeifferinella sp. infecting Pirenella conica. X2500.

Figs. 2, 3: Hepatopancreas showing multinucleated meront, contain number of nuclei, in a parasitophorus vacuole. Fig. 4: Multinucleated meront (M), showing peripheral distribution of nuclei.

Fig. 5: hepatopancreas showing mature meront with developed merozoites and well-formed merozoites.

Fig. 6: Light micrographs of different gamogonic stages of Pferifferinella sp. infecting P. conica. X2500.

Fig. 6: Light micrograph microgamont with peripheral distribution of nuclei within a parasitophorus.

Figs. 7\&8: Macrogamont with a central located nucleus and characteristic vaginal tube within a parasitophorus.

Fig. 9: Macrogamont with a centrally located large nucleus.

Fig. 10: Macrogamont with a central located large nucleus and microgamete, in syzygy manner.

Figs. 10-13: Sporogonic stages of Pfeifferinella sp. infecting $P$. conica.

Figs. 11\&12: Zygote or young oocyst with a centrally located nucleus with wall forming bodies within a parasitophorus. X2500.

Fig.13: Sporulated oocysts (OC) with eight naked sporozoites. X1100.

Figs. 14-16: TEM of different merogonic stages of Pfeifferinella sp. infecting $P$. conica. X15000

Fig. 13: Uninucleated meront with centrally located nucleus in a large parasitophorus vacuole, host cell.

Fig. 14: Multinucleated meront, showing nuclei in a large parasitophorus vacuole, host cell, host cell nucleus.

Fig. 15: Mature meront with peripherally arranged merozoites in a large parasitophorus vacuole, host cell, host cell nucleus.

Figs. 16\&17: Mature meront with peripherally located developed merozoites in a large parasitophorus vacuole.

Fig. 18: Uninucleated meront with centrally located nucleus in a large parasitophorus vacuole, host cell. X15000

Fig. 19: Multinucleated meront with peripherally nuclei in a large parasitophorus vacuole, host cell, host nucleus. $\mathrm{X} 15000$

Fig. 20: Mature meront with peripherally located developed merozoites in a large parasitophorus vacuole. X15000

Fig. 21: Mature meront with peripherally merozoites in a large parasitophorus vacuole, host cell, host cell nucleus. $\mathrm{X} 15000$

Fig. 22: Mature microgamont with many nuclei at periphery in a large parasitophros vacuole, in a host cell. X15000 Life cycle of Pfeifferinella $s p$. infecting $P$. conica: 1- sporozoite, 2- Uninucleated meront, 3- Multinucleated meront, 4Developing meront with merozoites. 5- Free merozoite, 6- Gamont, 7- Microgamont, 8- Macrogamont, 9- Microgam- 
ete, 10-Macrogamete, 11-syzygy, 12-Zygote, 13-Oocyst, 14-Oocyst with eight nuclei, 15- Oocyst with eight sporozoites
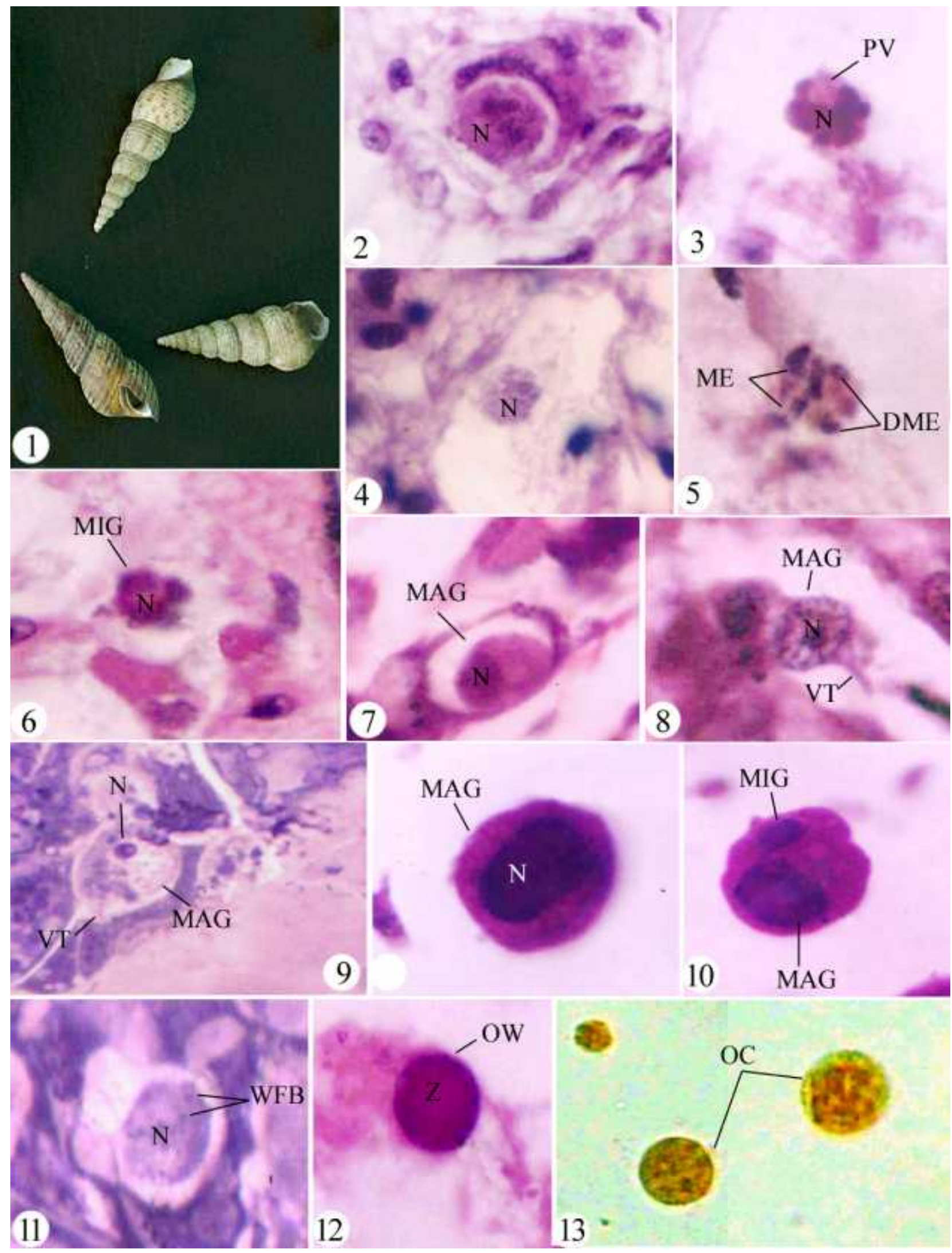

12

$13^{\circ}$ 

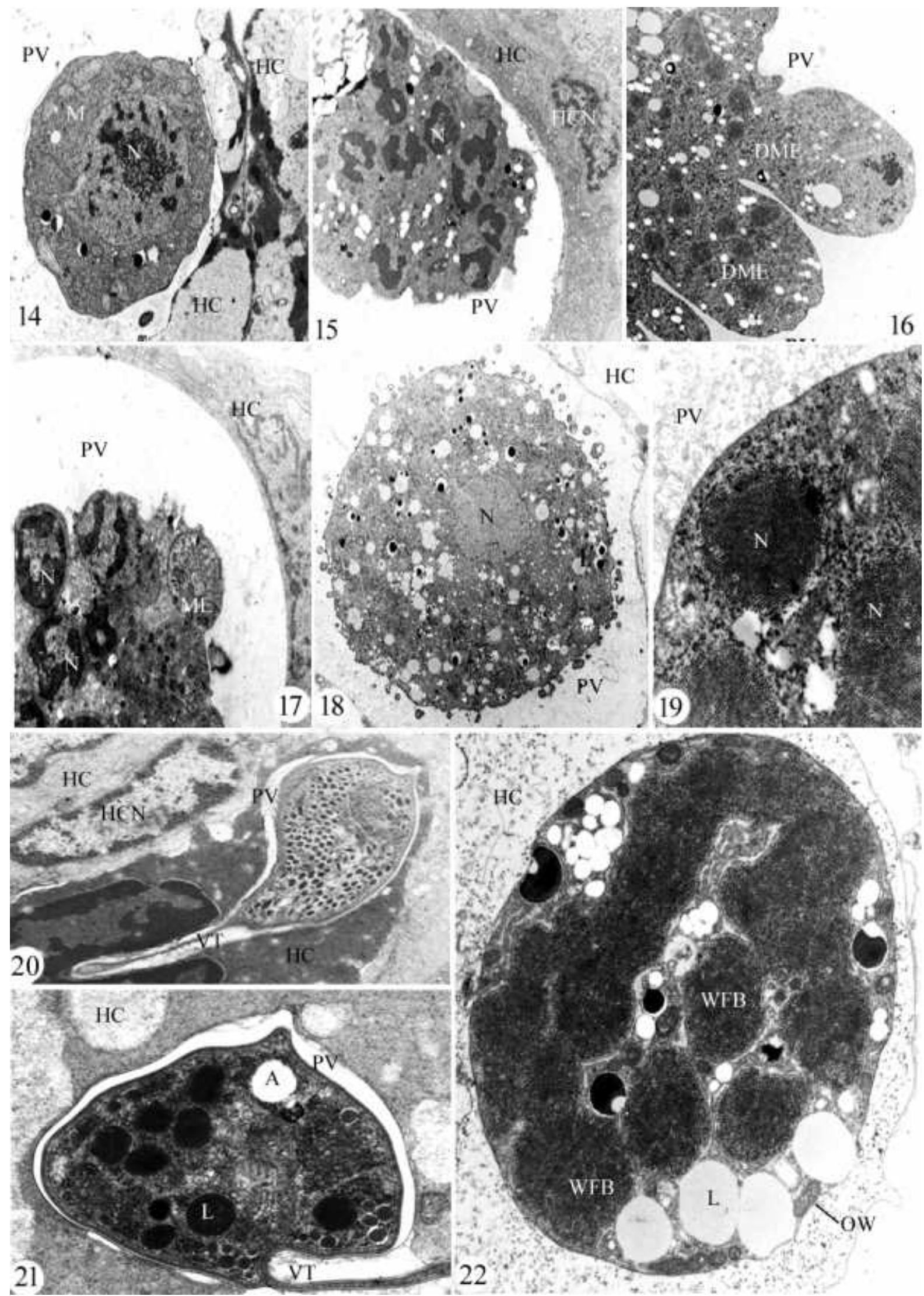


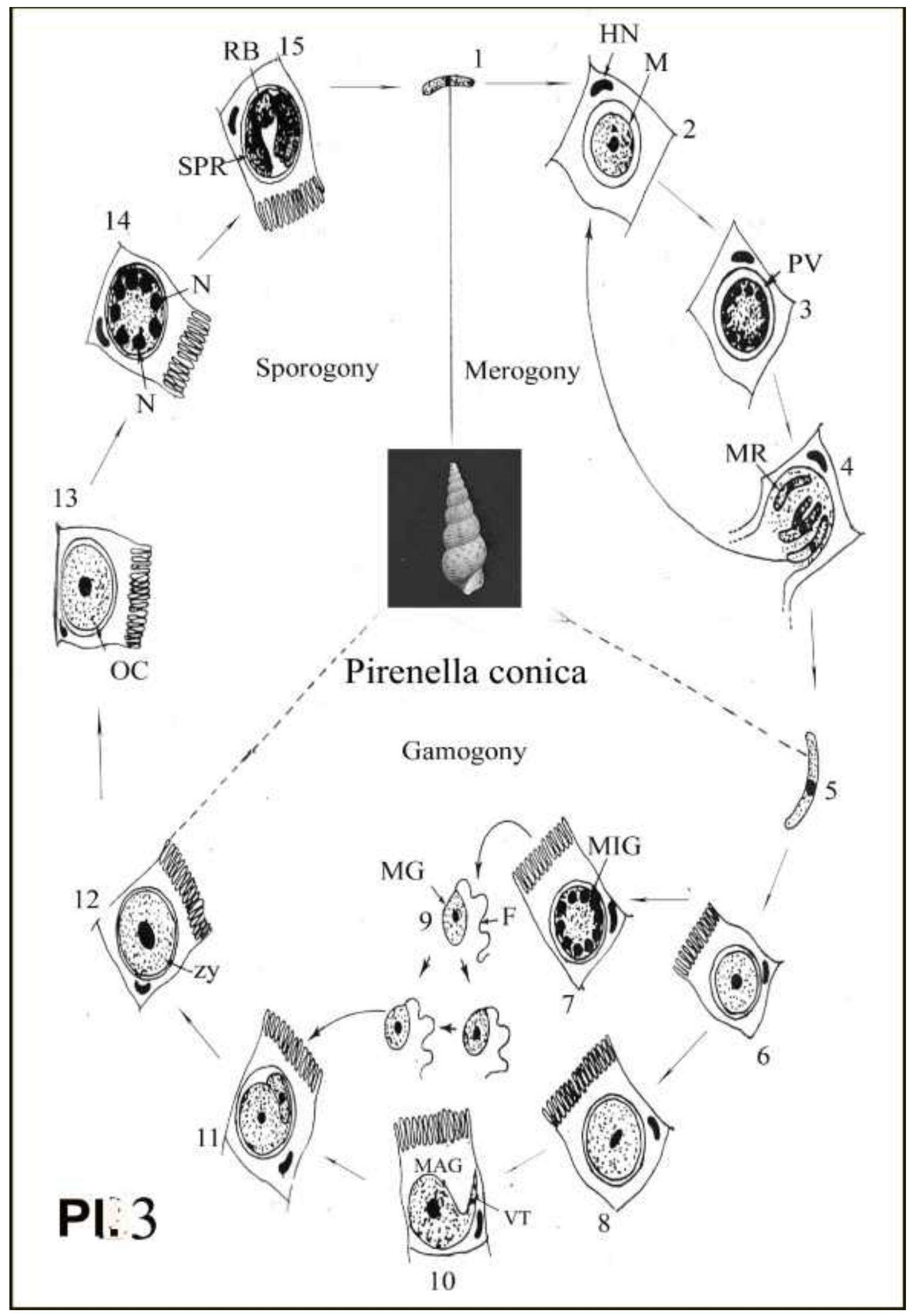

